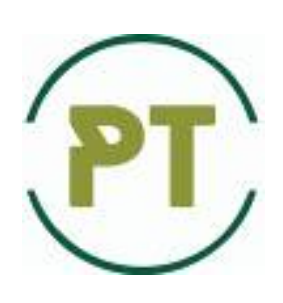

Problems of Tribology, V. 25, No 3/97-2020, 25-31

Problems of Tribology

Website: http://tribology.khnu.km.ua/index.php/ProbTrib

E-mail: tribosenator@gmail.com

DOI: https://doi.org/10.31891/2079-1372-2020-97-3-25-31

\title{
Simulation of a thin long rod that does not have critical forces and does not lose stability to Euler
}

\author{
A. Goroshko*, V. Royzman, S. Petraschuk \\ Khmelnitskyi National University, Ukraine \\ *E-mail: iftomm@ukr.net
}

\begin{abstract}
The paper proposes a method of preventing the loss of Euler stability by thin rods. Such rods do not have critical forces and therefore do not lose stability from longitudinal compressive force. The method is based on a temporary change in the stiffness of the rod-support system, in particular, a change in the length of the rod between the supports when approaching the value of critical forces, and after passing the return to the previous value. The results of simulation modeling of the rod behavior are presented, which confirm the possibility to eliminate the loss of its stability with increasing compressive force to the maximum allowable value, which is determined from the condition of strength.
\end{abstract}

Keywords: stable rods, critical force, bending modes, simulation, flexible rod.

\section{Introduction}

The work of long rods on critical (according to Euler) values of compressive forces leads to negative consequences, including major accidents and catastrophes. The only effective way to prevent the loss of stability of a compressed axial force of the rod is to reduce its slenderness ratio

$$
\lambda=l / i
$$

where $l$ is the estimated length of the rod, $i$ is the smallest radius of inertia of its cross section. At a given length, this leads to an increase in the weight of the structure.

Meanwhile, the creation of long rods that do not have critical compressive forces and that do not lose stability is in principle possible. The authors propose a method of temporary transformation of critical forces into non-critical ones according to Euler for a long thin elastic rod. This paper presents some results of research on the model of such a rod.

\section{Literature review}

The basic theory of a long thin rod in the elastic state was introduced by Euler [1, 2]. In the linear formulation, he considered the problem of finding the critical forces of a axial compressed elastic rod of constant cross-sectional length, resting at the ends on hinged supports. In the case of longitudinal bending, the external load is the bending moment $M_{z}=P_{c r} \cdot y$, created by longitudinal compressive force $P_{\text {cr }}$ with moment arm $y=f(z)[3]$.

The derivation is based on the approximate differential equation of the curved axis of the rod

$$
E I_{A} y^{\prime \prime}=M_{z} P_{c r} \cdot y,
$$

where $E-$ is Young's modulus of elasticity of the rod material; 
$I_{A}$ - is the second moment of area of cross section of the round rod (Fig. 1). This equation is easily reduced to the form:

$$
y^{\prime \prime}+k^{2} y=0,
$$

where $k=\sqrt{\frac{P_{c r}}{E I_{A}}}$.

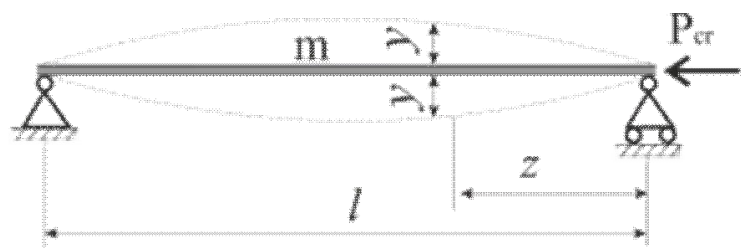

Fig. 1. To the derivation of the Euler formula

The general solution of the second-order differential equation (2) has the form

$$
y=A \cos k z+B \sin k z,
$$

where $A$ and $B$ are arbitrary constants determined from the boundary conditions, that is, the conditions for fixing the ends of the bar on the supports. Since the bar freely rests on supports, one of which is hinge-fixed, and the other is hinge-movable, the integration constants are determined from the conditions for zero deflections and bending moments on these supports, that is

$$
\begin{aligned}
& y=0 \text { at } z=0 \text { and } z=l ; \\
& y^{\prime \prime}=0 \text { at } z=0 \text { and } z=l .
\end{aligned}
$$

After substituting these conditions in (3) and solving these equations we obtain: $A=0, B \sin k l=0$. This is only possible if either $B=0$, either $\sin k l=0$. If $A=B=0$, this means that the deflections y are absent, which contradicts the condition of the problem. If we accept $\sin k l=0$, then the constants $A$ and $B$ can take arbitrary values, and the deflection $y$ can be arbitrary, including infinitely large, which corresponds to a state of indifferent equilibrium, i.e. the loss of stability of the rod under the action of critical compressive force The condition $\sin k l=0$ is satisfied when, $k l=\pi n$, where $n \in \mathbb{N}$ are natural numbers. Hence, $k=\frac{\pi n}{l}$, where taking into account (2) we have Euler's formula:

$$
P_{c r}=\frac{n^{2} \pi^{2}}{l^{2}} E I_{A}
$$

Thus, the rod has an infinitely large number of critical Euler forces, which relate to each other as squares of natural numbers $n$. From equation (3) it follows that the equation of the elastic line of the rod has the form $y=B \sin k z$.

Euler's theory was later developed by many scientists, including Grashof [4], Yasinsky [5], Timoshenko and Gere [6]. In the works of modern authors, for example [7 - 12], the issues of loss of stability by thin rods loaded with longitudinal force, such as the limits of correct application of Euler's formula, the relationship with flexibility, the behavior of the rod in the zone of plasticity, etc. are investigated and clarified. However, the issue of avoiding the loss of stability due to the temporary transformation of critical forces into non-critical ones has not been studied at all.

\section{Purpose}

The purpose of the work was to study the peculiarities of the process of loss of stability according to Euler of thin rods and to substantiate the method of its prevention by means of simulation modeling.

\section{Presentation of research materials}

For the first critical force, the shape of the curved axis contains one half-wave of a sinusoid, for the second critical velocity and the second critical force - two half-wave sinusoids, i.e. a full wave (sinusoid), for the 
third three half-wave sinusoids, and so on. Thus, each value of the critical force corresponds to its identical forms of loss of stability (Fig. 2).

If we take advantage of the fact that higher (than the first) forms of loss of stability are in themselves unstable without the presence of intermediate supports in the nodes of the forms, we can offer the following method of preventing critical states of the rod.

To prevent the manifestation of the first critical force is necessary against the middle of the length of the $\operatorname{rod}($ p. $A$ ) at a distance of the allowable deflection of the rod. Whereas as soon as the values of the compressive forces approach the critical values and the deflections begin to increase, the rod, losing stability, will touch the support in the inaccuracy of the sinusoid, i.e. in the middle of the length $l$; this length will be "divided" into two halves and will now be a critical force for him

$$
P_{c r 2}=\frac{\pi^{2}}{(l / 2)^{2}} E I_{A}=\frac{4 \pi^{2}}{l^{2}} E I_{A}
$$

and the rod will withstand an increase in compressive strength up to $P_{c r 2}$.

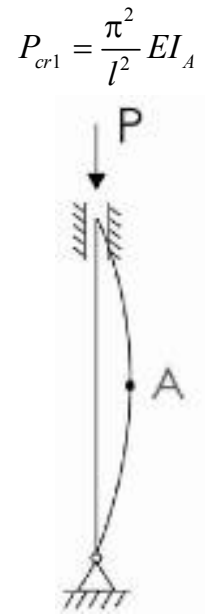

the first mode

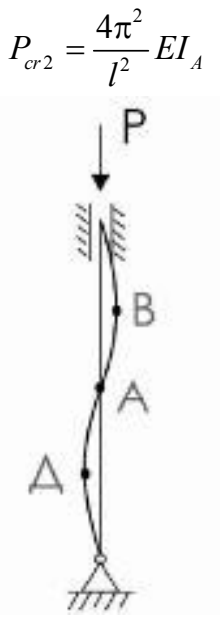

the second mode

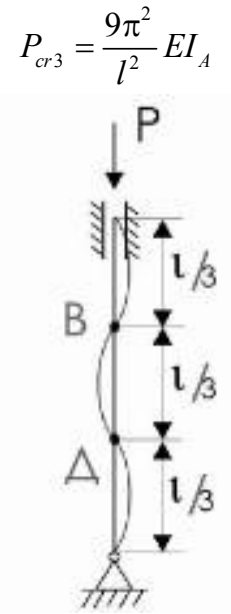

the third mode

$$
P_{c r n}=\frac{n^{2} \pi^{2}}{l^{2}} E I_{A}
$$

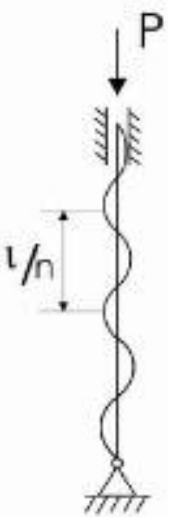

the fourth mode

Fig. 2. Forms of loss of stability at critical forces

Similarly, in order to prevent the manifestation of the second critical force, it is necessary to place supports with a gap equal to the allowable deflection against the points of the $\operatorname{rod} B$ and $D$. At these points, there must be an antinode at the loss of stability, which corresponds to the values of the second critical force. Then, as soon as the value of the compressive force approaches the second critical value, the rod will begin to lose stability in the second form of bending and will touch the support at points $B$ and $D$ and its length will be "divided" into three parts of length $1 / 3$. Now the critical force for the rod will be $P_{c r 3}=\frac{9 \pi^{2}}{l^{2}} E I_{A}$, and the rod will withstand an increase in critical force to $P_{c r 3}$.

In general, the idea of creating a rod that does not have critical forces in practice, ie one that does not lose stability from the longitudinal compressive force is based on the automatic change of stiffness of the rod-support system, for example, changing the length of the rod between supports when approaching critical forces. After the passage, the stiffness returns to the previous value, which makes it possible to eliminate the loss of stability with increasing compressive force to the maximum allowable value, which is determined from the condition of strength. In this case, to eliminate the critical states of the rod by one, two, three, etc. own forms of loss of stability of the deflection-deflection deflection should be installed in places of maximum deflection (antinodes) of the corresponding forms.

If stability loss is to be eliminated for all critical forms, then one of such supports limiting deflection is installed along the entire length of the rod. When the value of compressive force approaches to the next critical value, deflections grow in the corresponding sections of the rod. When gap is reached the rod will collide with deflection limiters installed in the indicated sections, and thus it will receive additional supports reducing its length between supports, which, as seen from formula (4), changes (increases) the value of critical force. Therefore rod will no longer be in condition of indifferent equilibrium, which meant loss of stability, and it will be able to harmlessly transit the values of compressive forces, which now, when touching the bearings, are no longer critical. When the speed of rotation or the value of compressive force approaches to the next critical value, other sections of the rod will touch the deflection limiter and the system stiffness will change, similarly to the manner described above, and these values will no longer be critical and will not lead to loss of stability. 
The implementation of the idea of creating a rod that has no critical compressive forces can be seen, for example, in the design of recoil devices of some artillery guns with hydraulic recoil brake. When firing, the barrel under the action of recoil rolls back, squeezing the rod in the form of a long rod, which carries at the opposite end of the piston with holes, which moves in a cylinder filled with brake fluid. This rod is enclosed in a shell and this design prevents the loss of stability of the rod under the action of retractable compressive force.

Creating a simulation model of the rod that does not lose stability. To test the feasibility of the practical implementation of the proposed method, tests were conducted on a specially designed simulation model. A visual programming system Simscape Multibody was used to model the flexible rod as a massive body with distributed mass. It is a multi-body modeling environment for 3D-mechanical systems that formulates and solves the equation of motion for the entire mechanical system.

The horizontally located steel rod of round section with the parameters given in table 1 was modeled. Under the action of the weight of the rod, its static deflection is equal to $y_{0}=0,21 \mathrm{~mm}$. Fastening method is hinged (one support is hinged-fixed, the other - hinged-movable). To simulate a flexible rod, a method of approximating a flexible body with a fixed set of discrete flexible bodies with lumped-parameter method was used. [13]. This approach approximates flexible body as a set of $N$ solids connected by $N-1$ springs and dampers. Shaft elements connected in series with dampers and springs provide concentrated rod inertia. The springs realize the degree of freedom of the system. Each mass has three degrees of freedom: two rotational degrees of freedom in the directions $\mathrm{X}$ and $\mathrm{Y}$, perpendicular to the axis of the rod $\mathrm{Z}$, which allow bending deformation, and a translational degree of freedom in the $\mathrm{Z}$ direction for axial tensile-compressive deformation (Fig. 3).

Table 1

\section{Parameters of the modeled rod}

\begin{tabular}{|c|c|c|c|}
\hline Length $L$ & Diameter $D$ & Slenderness ratio $\lambda$ & Young's Modulus, $\mathrm{E}$ \\
\hline $1 \mathrm{~m}$ & $20 \mathrm{~mm}$ & 100 & $210 \mathrm{e} 9 \mathrm{~Pa}$ \\
\hline
\end{tabular}

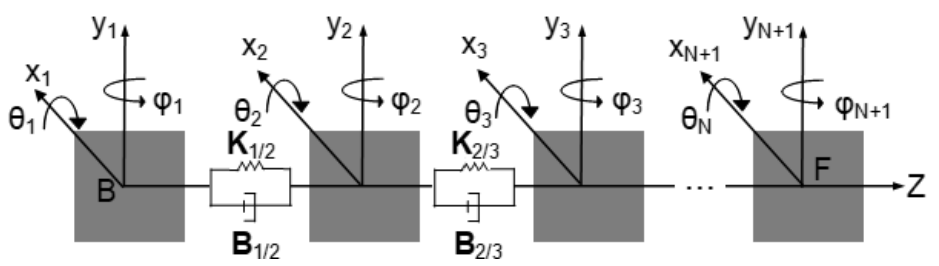

Fig. 3. Approximation of a flexible rod with distributed mass a set of flexible elements with a concentrated mass

The number $N$ of elements «Flexible Element» partially affects the accuracy of the model, the spatial shape and the speed of calculation of the model. Increasing $N$ allows to achieve greater accuracy, however, due to higher computational costs. Therefore, the value of $N$ was chosen experimentally and was $N=20$ for the rod investigated.

The stiffness and internal viscosity coefficients are functions of the material properties and geometry of the flexible elements and are the same for all elements. In the considered model the linear model of damping is accepted (Fig. 4). In particular, for axial deformation there is a dependence:

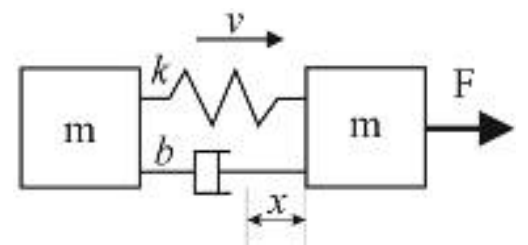

Fig. 4. «Flexible Element» with one degree of freedom of translational movement

length of anundeformed flexible beam.

$$
F=-k_{a} x-b_{a} v
$$

where $k_{a}$ the translational spring coefficient of the joint, $x$ is the translational offset, $b_{a}$ is translational damping coefficient of the joint, $v$ is linear velocity. The spring coefficient is defined as:

$$
k_{a}=E A / l
$$

where $A$ is the cross-sectional area of the beam, $l=L / N$ is the

To deformation the bend of the flexible element, the dependence of the torque is written as:

$$
\tau=-k_{r} \gamma-b_{r} \omega
$$

where $\tau$ is the spring torque, $k_{r}$ is the rotational spring constant, $\gamma$ is the deflection angle, $b_{r}$ is the rotational damping coefficient of the joint, $\omega$ is the natural frequency (Fig. 5). 


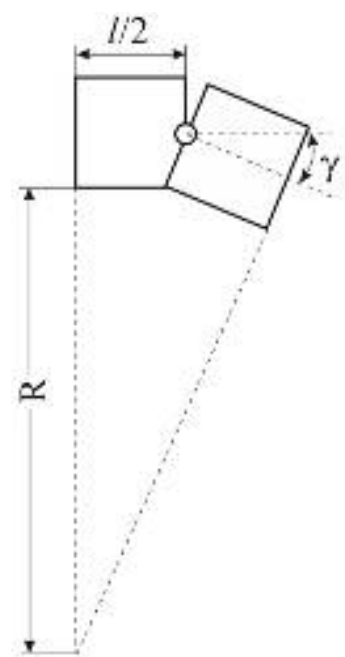

Fig. 5. «Flexible

Element» with one degree of freedom of rotation
The bending moment $M$, acting on the element is equal to:

$$
M=\frac{E I_{A}}{R},
$$

where $I_{A}$ is the second moment of area, $R$ is the bending radius of curvature.

At small deformations it is lawful to accept that $\gamma \rightarrow \frac{l}{R}$, therefore equating the torque that follows from Hooke's law $\tau=k_{r} \gamma$ and bending moment $M$, the spring coefficient becomes [14]:

$$
k_{r}=\frac{E I_{A}}{l} .
$$

The translational damping coefficient $b_{a}$ and the rotational damping coefficient $b_{r}$ (viscous friction) of the model were set empirically. They were found by comparing the attenuation rate of free oscillations in the rod and its model [15]. Verification of the finished model was performed based on the specified deflection $y_{0}$ from its own weight, as well as the rate of damping of the natural oscillations of the rod.

To limit the bending, the rod model was placed in a tube model with an inner diameter $d_{t}=D+2 y_{\max }$, where $y_{\max }=8 \mathrm{~mm}$ is max allowable deflection for rod (Fig. 6). Elements «Translational Hard Stop» were used to simulate the boundary tube for each of the $N$ elements of the rod. Such elements limit the translational motion in the plane perpendicular to the axis of the rod by elastic shock interaction. The scattering of the rod impact energy against the pipe was not taken into account.

Results of numerical experiment and modeling. The created model was investigated in the range of values of longitudinal compressive force $P=0 \ldots 70 \mathrm{\kappa N}$ so as not to exceed the allowable stresses based on the strength condition. The experimentally found value of the first critical force was $P_{c r 1}=14,7 \mathrm{kN}$. In Fig. 6 (a) the first form of bending of a rod at value of force $P_{k p 1}$ is shown.
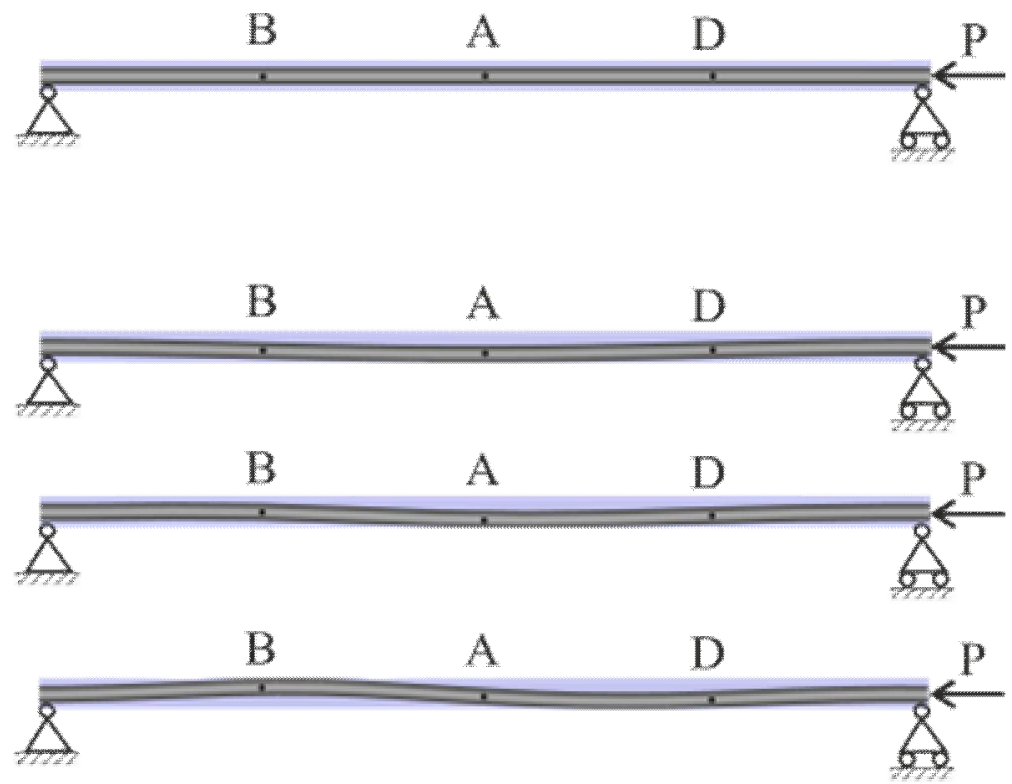

Fig. 6. 3D-model of the rod and the shape of its bend in the tube: a -3D-model of a rod bounded by a tube;

$b$ - the first bending mode of the corresponding $\operatorname{rod} \mathbf{P}_{c r 1}$;

$c$ - change the shape of the rod when approaching $\mathbf{P}_{c r 2}$;

$\mathrm{d}$ - the second bending mode of the corresponding $\operatorname{rod} \mathbf{P}_{c r 2}$

The rod was deformed, its maximum deflection was limited by the pipe and was $8 \mathrm{~mm}$, which is the maximum allowable deflection for the test rod. Having obtained the third resistance in the section from point $A$, further deformation of the cross section of the $\operatorname{rod}$ in point $A$ became impossible. The reaction force of the third support at the point where it was touched by the rod was small $R_{A}=1 \mathrm{KN}$. 
Increasing the axial load to the level $P>P_{c r 1}$ led to the deformation of other sections, although in general the rod remained curved in the first form directly to $P_{c r 2}$, which is shown in Fig. 6 (c). When the load increases $P=P_{c r 1} \ldots P_{c r 2}$ the reaction force of the third support decreased to zero $R_{A} \rightarrow 0$. When approaching the value $P_{c r 2}=57,2 \mathrm{kN}$ the rod lost the first form of bending and sharply acquired the second form of bending, shown in Fig.6 (d). In this case, the rod touched the limiters in sections $B$ and $D$ and has already received two additional supports. The corresponding absolute values of the reaction forces where $R_{B}=R_{D}=2 \mathrm{KN}$. These forces are maximum at the time of acquisition and gradually decrease to zero with a subsequent increase in axial load and deformation of the rod. Thus, the rod withstood the value of the second critical force and began to resist the axial force (Fig. 7, 8).

Modeling of the rod behavior with a further increase in load was not performed, as it would lead to an increase in stresses in the material above the limit of proportionality.

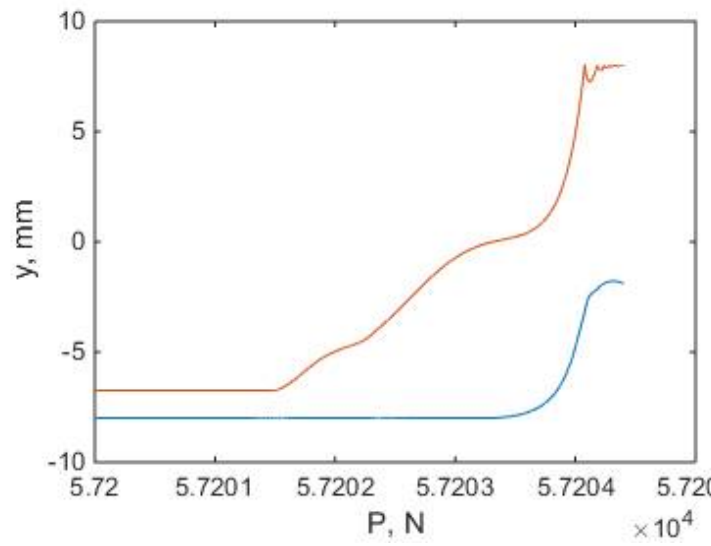

Fig. 7. Dependence of deflection at points $A$ and $B$ on applied load

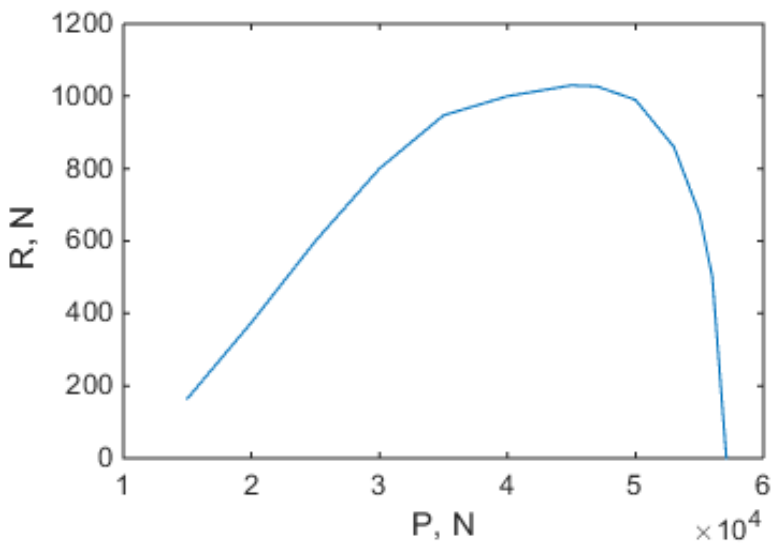

Fig. 8. Dependence of the reaction force at the point of contact rod with limiter (point A) from the load

\section{Conclusions}

The results of the study showed the fundamental possibility of creating and practical application of structures with rods that do not have critical Euler forces and do not lose stability. The general idea of creating structures that do not have states of indifferent equilibrium is that they should be able to change their properties (parameters) when approaching such states, and after its passage to return to the original properties. These design parameters can at a given moment change their quantitative values automatically or forcibly at the command of the operator by changing the stiffness, mass, length, number of supports and other factors that determine the quantitative values of indifferent equilibrium parameters, for example, when reaching the maximum allowable deformations construction.

These design parameters can change their quantitative values automatically or forcibly at the command of the operator at a given time. The values of stiffness, mass, length, number of supports and other factors that determine the quantitative values of the parameters of indifferent equilibrium states can change, for example, at the time of achieving the maximum allowable deformation of structural elements.

\section{Funding}

The research was funded by the Ministry of Education and Science of Ukraine (Project No. 0120U102067).

\section{References}

1. Euler L., 1744. Methodus inveniendi lineas curves maximi minimive proprietate gaudentes. Appendix 1. De curvis elasticis (in Latin). Lausanne and Geneva. (op.cit.) (op.cit.)

2. Euler L., 1759. Sur la force de colonnes (in French). Memoires de l'Academie de Berlin, 13, $251-282$.

3. Pisarenko S. S. Strength of materials. K. : «Technics», 1967. - 791 p. (in Russian)

4. Grashof F., 1878. Theorie der Elasticität und Festigkeit. Berlin (op.cit.)

5. Yasinsky F.S. Experience in the development of the theory of buckling. // F.S. Yasinsky. Selected papers on the stability of compressed rods. - M. - L .: Gostekhizdat, 1952 .- p. 138-194 (in Russian)

6. Timoshenko S. P., Gere J. M., 1963.Teoria stateczności sprężystej. Arkady Warszawa. 
7. Lembo, Marzio. (2003). On the stability of elastic annular rods. International Journal of Solids and Structures. 40. 317-330. 10.1016/S0020-7683(02)00546-2.

8. Karimbaev K.D., Palchikov D.S. About criteria of loss of stability of the squeezed cores outside elasticity at rigid loading // Vestnik of Ufa State Aviation Technical University. Vol. 19. 3 (69). (2015) 126-131.

9. Murawski K. The Euler's modified theory of stability with stresses and strains analysis on example of very slender cylindrical shells made of steel. Acta Scientiarum Polonorum, Architectura, 3(1) 2004

10. Sharafutdinova G. G. An operator method for studying the Euler problem on types of the loss of stability for a pivoted rod under buckling load. Russian Math. (Iz. VUZ), 54:11 (2010), 77-82

11. Glazkov T. V. Критическая нагрузка стержня с начальной неправильностью / Т. В. Глазков. Текст : непосредственный // Молодой ученый. — 2015. — № 23 (103). — C. 125-129.

12. Bekshaev S. Ya. On the optimal position of the intermediate support of a three-span rod // Bulletin of Odessa State Academy of Civil Engineering and Architecture. 60 (2015) 400 - 406.

13. V Chudnovsky, A Mukherjee, J Wendlandt, D Kennedy Modeling flexible bodies in simmechanics //MatLab Digest. - Vol. 14 (3) (2006).

14. Miller S. et al. Modeling flexible bodies with simscape multibody software //An Overview of Two Methods for Capturing the Effects of Small Elastic Deformations, MathWorks. - 2017.

15. Zmeu K.V., Notkin B. S., Kovalyov V.A., Vara A.V. Modeling the Flexible Mechanical System In Matlab for Control System Synthesis // Izvestia of Samara Scientific Center of the Russian Academy of Sciences. 1-2. (2012).

Горошко А.В., Ройзман В.П., Петращук С.А. Моделювання тонкого стрижня, що не має критичних сил і не втрачає стійкості за Ейлером.

У роботі запропоновано метод недопущення втрати стійкості за Ейлером тонкими стрижнями. Такі стрижні не мають критичних сил і тому не втрачають стійкість від поздовжньої стискувальної сили. Метод базується на тимчасовій зміні жорсткості системи стрижень-опора, зокрема, зміні довжини стрижня між опорами при наближенні до значення критичних сил, а після проходу поверненні до попереднього значення. Представлені результати імітаційного моделювання поведінки стрижня, які підтверджують можливість усунути втрату його стійкості при зростанні стискувальної сили до максимально-допустимого значення, який визначається з умови міцності.

Ключові слова: стійкість стрижня, критична сила, форми згину, моделювання, гнучкий стрижень. 